\title{
The Dynamics of Entry, Exit and Profitability: An Error Correction Approach for the Retail Industry
}

\begin{abstract}
We develop a two equation error correction model to investigate determinants of and dynamic interaction between changes in profits and number of firms in retailing. An explicit distinction is made between the effects of actual competition among incumbants, new firms competition and potential competition from firms outside the market. Effects of cost, demand and general income changes on profitability are investigated to gain insight in the role of retailing in the cost, demand and wage inflationary processes. The relative importance of profitability, growth and unemployment as determinants of net entry are studied. The model is tested using a panel data set of 36 Dutch shoptypes covering the $1977-1988$ period.
\end{abstract}

\section{Introduction}

Investigation into the determinants of profitability and entry and exit accounts for a large share of the empirical industrial organization literature (see Schmalensee (1989)). Most studies are confined to manufacturing industries, lack modelling of the dynamic interaction between profitability, entry and exit and deal only partly with competition as a determinant of profitability. This paper makes a contribution to the existing literature with respect

Final version received September 3, 1993.

Centre for Advanced Small Business Economics

Erasmus University Rotterdam

P.O. Box 1738, 3000 DR Rotterdam,

The Netherlands

and

Department of Fundamental Research

Research Institute for Small and

Medium-Sized Business

P.O. Box 7001, 2701 AA Zoetermeer,

The Netherlands to these three limitations. First, we explicitly focus on one of the major service industries, viz. the retail trade. Retailing has a strong contribution to the economy: for instance, in the Netherlands it accounts for about $23 \%$ of total number of economically active enterprises and for about $13 \%$ of total labour force in the private sector in 1988 (source: Bode (1990)). In our investigation of the determinants of profitability in retailing we will also pay attention to the role of this industry in the inflationary process. We provide results on the influence of retail pricing practice on cost, demand and wage inflation. Second, the dynamic interaction between profitability and number of firms is modelled using a two equation error correction model. This is done because high profitability attracts new firms, whereas a rise in the number of firms creates a pressure on profitability. Third, we distinguish explicitly between three sources of competition, viz. competition of existing firms, competition of new firms and potential competition, in our explanation of changes in profits.

The model discussed in Section 2 can effectively determine the importance of different sources of competition as well as different sources of inflation and is applicable in structure-conductperformance studies in general. Our starting point is the Kirznerian notion of entrepreneurship being the alertness to profit opportunities. From this we develop an error correction framework which extends the persistence of profits literature into a more complete dynamic market modelling.

The structure of the paper is as follows. In Section 2 we set up the model and develop a number of hypotheses concerning the effects of the variables incorporated. Section 3 describes our data set of 36 shoptypes for the period 19771988. Section 4 presents the empirical results of 
the model estimated on the entire data set and on selected subsets. We summarize and provide recommendations for future research in Section 5 .

\section{Modelling profitability and net entry}

Entrepreneurs seek to discover and exploit hitherto unnoticed profit opportunities. This competitive activity pushes prices in directions which gradually squeeze out further profit-making opportunities. This formulation of the competitive-entrepreneurial process as used by Kirzner $(1973,1979)$ is of essential importance for the measurement of market competition and efficiency. As Kirzner (1973, p. 6) puts it: "The efficiency of the price system ... does not depend upon the optimality (or absence of it) of the resource allocation pattern at equilibrium; rather, it depends on the degree of success with which market forces can be relied upon to generate spontaneous corrections in the allocation patterns prevailing at times of disequilibrium." The persistence of profits literature, which started with Mueller (1977), investigates to what extent and with what speed these competitive forces adjust profits to long-run competitive levels. In this study we extend this approach to a more complete modelling of industry dynamics, which not only allows for studying the extent of different competitive forces in an industry, but can also be used to study the role of an industry in the inflationary process and to investigate the relative importance of determinants of entry and exit.

Entrepreneurial activity is the fundamental generator of the error correction mechanism in our model. The notion that entrepreneurs restore equilibrium by a sequence of adjustments to disequilibrium situations has been expressed by various students of entrepreneurial behaviour. Schultz (1975) defines entrepreneurship as the ability to deal with disequilibria, whereas Kirzner $(1973,1979)$ emphasizes the perception and exploitation of profit opportunities as its main feature. ${ }^{2}$ In his view competition and entrepreneurship coincide because the competitive market process is basically entrepreneurial. Essential to this concept of competition in market-process theory is "the free entry of rivals, each in a incessant race to better the others" (Ikeda (1990), p. 79).

In this study the entrepreneurs are (potential) small independents in retailing. Our model is set up to explain changes in profits and number of firms for these small independents. Disequilibrium is expressed in terms of excess profits. As a small independent's profit generally equals his income (before taxes), we define excess profit as the difference between this profit and gross modal wage. Shoptypes with positive excess profits are assumed to be attractive to enter. This is the basic idea behind our modelling of the dynamic interaction between profitability and net entry. Our model consists of two equations and is of an error correction mechanism type (see Gilbert (1986) and Salmon (1982)).

$$
\begin{aligned}
\Delta \pi_{i t}-\Delta Q_{i t}= & \alpha_{0}+\alpha_{1}\left(\pi_{i, t-1}-M I_{t-1}\right)+ \\
& +\alpha_{2} \Delta N O F_{i t}+\alpha_{3} \Delta T U R_{i t}+ \\
& +\alpha_{4} \Delta M I_{t}+\alpha_{5}\left(\Delta K_{i t}-\Delta Q_{i t}\right)+ \\
& +\alpha_{6} \Delta \Delta C S_{i t}+\varepsilon_{i t} \\
\Delta N O F_{i t}= & \beta_{0}+\beta_{1}\left(\pi_{i, t-1}-M I_{t-1}\right)+\beta_{2} \Delta C S_{i, t-1}+ \\
& +\beta_{3} U N_{t-1}+\beta_{4} \Delta N O F_{i, t-1}+ \\
& +\beta_{5} \Delta T U R_{i t}+\eta_{i t}
\end{aligned}
$$

In these equation $\varepsilon_{i t}$ and $\eta_{i t}$ are possibly correlated random errors and the variables are logarithms of:

$\pi_{i t} \quad$ : average profit in shoptype $i$ in year $t$ in 1980 prices

$Q_{i t} \quad$ : average value of sales in shoptype $i$ in year $t$ in 1980 prices

$M I_{t} \quad$ : modal income in year $t$ in 1980 prices

$C S_{i t}$ : consumer spending for the product package sold in shoptype $i$ in year $t$ in 1980 prices

$N O F_{i t}$ : number of firms in shoptype $i$ in year $t$

$T U R_{i t}$ : sum of number of firms entering or leaving shoptype $i$ in year $t$

$K_{i t} \quad$ : average value of total costs in shoptype $i$ in year $t$ in 1980 prices

$U N_{t} \quad$ : number of unemployed in 1,000 persons in year $t$

The market "error" in our model, which presents an opportunity for entrepreneurial action, is the difference between profit and modal income. More precisely, in case $\alpha_{1}$ is negative and $\beta_{1}$ positive, we find all $\pi_{i t}$ exceeding $M I_{t}-\alpha_{0} / \alpha_{1}$ in long term equilibrium to have a downward effect on profitability, while all $\pi_{i t}$ exceeding $M I_{t}-\beta_{0} / \beta_{1}-$ 
$\beta_{3} U N_{t} / \beta_{1}$ in long term equilibrium lead to a larger number of firms, which again squeezes profitability in case $\alpha_{2}$ is negative. We expect $\alpha_{0} / \alpha_{1}$ to be negative because independents not only supply labour but also are to be compensated for their managerial responsibilities and risk borne on their capital investment. The benchmark level of profit for net entry, $M I_{t}-\beta_{0} / \beta_{1}-\beta_{3} U N_{t} / \beta_{1}$, depends on the number of unemployed. High unemployment stimulates potential independents to enter and demotivates incumbants to exit. A disequilibrium on the labour market therefore generates entrepreneurial activity which may exert a downward pressure on disequilibria in the product markets, i.e. on excess profits. Note that an error correction on the number of firms is not incorporated because of lack of a long-term benchmark for this variable. ${ }^{3}$ The long-term relationship between profits, modal income and unemployment is easily derived as:

$$
\begin{aligned}
\pi_{i t}= & M I_{t}-\left\{\alpha_{0}+\alpha_{2} \beta_{0} /\left(1-\beta_{4}\right)+\right. \\
+ & \left.\alpha_{2} \beta_{3} U N_{t} /\left(1-\beta_{4}\right)\right\} \\
& \left\{\alpha_{1}+\alpha_{2} \beta_{1} /\left(1-\beta_{4}\right)\right\}
\end{aligned}
$$

We will now discuss the effect of the variables incorporated in equations (1) and (2) and subsequently our main research questions.

High excess profit (profit minus modal income) will generally lead to increasing competitive pressures, both from within the shoptype as well as from diversifying firms in other shoptypes and even other industries (e.g. wholesale traders or manufacturers of consumer goods). The extent to which high profit levels can be maintained is an indicator of the pressure of the competitive environment. The parameter $\alpha_{1}$ measures this effect of competition from existing (or diversifying) firms and is expected to be negative. ${ }^{4}$

An increase in the number of firms will lead to an increase in competition. This will be the case especially in retailing, because new firms have to gain a considerable local market share (Porter (1976)). This is caused by the limited size and strong geographical separation of markets in retailing. A negative value of $\alpha_{2}$ is consistent with this view. However, entry and exit are most widespread in the group of relatively small firms who make up the competitive fringe (MacDonald (1986)). This implies that most entry and exit decisions may have only a limited direct effect on the industry's intensity of competition. ${ }^{5}$

Large entry and exit flows in a shoptype indicate low entry and exit barriers (see Dumne, Roberts and Samuelson (1988) and Van Herck (1984)). Market turbulence, TUR it, is used as indicator of the height of these barriers. ${ }^{6}$ In case potential competition should have an effect on profitability in retailing, we would expect $\alpha_{3}$ to be negative: rising entry barriers will decrease the threat of entry.

The profits of shopkeepers are largely a reward for their labour. A change in general income level, $\Delta M I_{t}$, may invoke shopkeepers to revalue their obtained profit level when compared to modal income. Profitability may therefore be affected as a result of economy-wide changes in wage levels. This implies a positive $\alpha_{4}$.

Short-term cost shifts are likely to be only partially passed on to customers. A negative $\alpha_{5}$ would support this practice of shopkeepers. If $\alpha_{5}$ equals zero changes in the cost-output ratio do not influence the profit-output ratio: costs shifts are entirely passed on within a one year period. Longterm cost changes will be entirely passed on in the case of negative $\alpha_{1}$ through the elimination of disequilibrium by the error correction mechanism.

A growing demand for retail services is assumed to facilitate increasing prices. This indicates a positive value for $\alpha_{6}$. The use of $\triangle \Delta C S_{i t}$ instead of $\triangle C S_{i t}$ is theoretically supported by Liebowitz (1982), who regards sales growth minus past sales growth as a more accurate predictor of change in profit rates than sales growth. It is also in line with the mark-up model of Nooteboom (1985), where the level of profit margins are hypothesized to be influenced positively by percentual changes in consumer spending.

High excess profits provide an incentive to enter a shoptype. ${ }^{8}$ We therefore expect $\beta_{1}$ to be positive. ${ }^{9}$ An upward swing of consumer spending for the product package sold in the shoptype will encourage entry and discourage exit. This implies a positive value for $\beta_{2}{ }^{10}$ Entrepreneurs' profit expectations will not be exclusively based upon incumbants' present profits, but also upon the market room as indicated by market growth.

Shopkeepers are less inclined to exit when job opportunities are poor. Additionally, unemployed may try to become self-employed in retailing to 
improve upon their financial situation. Evans and Leighton (1989a) present evidence that unemployed workers are more likely to enter selfemployment than employees. Storey and Jones (1987) find local labour market conditions to influence local rates of new-firm formation much stronger than profitability: job losses seem to make way for creation of new enterprises. ${ }^{11}$ A positive $\beta_{3}$ is expected.

As the net entry equation (2) suffered from severe autocorrelation, we adjusted this equation by incorporating the lagged dependent variable $\triangle N O F_{i, t-1}$. There are also theoretical grounds for the incorporation of this variable. First, many new entrants may not be very successful. Excessive net entry can therefore negatively influence next period net entry, implying a negative value for $\beta_{4}$. Second, high entry rates, just like high profits and high growth, can be an indicator for individuals of the success of a shoptype: entrepreneurs follow the success of earlier entrants. ${ }^{12}$ Examples can be encountered in the computer trade and management consultancy. This would be a reason to expect a positive $\beta_{4}$.

The change in turbulence is included in the net entry equation (2) to examine the influence of the changing importance of entry and exit barriers on net entry throughout the life cycle of a shoptype Following Porter (1976), we expect these barriers to rise in time in view of the progressive filling of "geographical gaps". In the beginning of a life cycle a shoptype is characterized by growing turbulence and high net entry rates. At the end of a life cycle turbulence is low and net entry will be negligible. ${ }^{13}$ We expect a positive $\beta_{5}$.

Our choice of specification of the model enables us to investigate the following research questions:

(1) How important are actual competition of existing and new firms and potential competition in the determination of profitability? Is the common idea confirmed that effects of potential competition are less important than that of actual competition (see for example Gilbert (1989))? Does the process of dynamic competition indeed erode excess profits over time?

(2) What is the role of retailing in the inflationary process? Can we consider retailing to be a subduing factor in cost inflation? Does changing demand create changes in profit margins, the so-called demand inflation? Do changes in general income level have an effect on profitability in retailing?

(3) Does the importance of the sources of competition differ between a period of economic growth and of decline? Can we consider short-term cost changes to be equally quickly passed on to customers over such periods?

(4) Are larger firms capable of passing on cost changes to their customers more quickly than small firms? Is small and large firm net entry influenced by the same incentives?

The first two research questions are directly connected to the six parameters of the profitability equation (1). The effect of actual competition of existing and new firms are measured by $\alpha_{1}$ and $\alpha_{2}$, respectively, and the effect of potential competition is measured by $\alpha_{3}$. If one of these parameters equals zero, the source of competition captured by this variable has no effect on profitability. The demand inflation effect can be connected to $\alpha_{6}$, the effect of wage inflation to $a_{4}$ and the adjustment of retail prices to changing costs, the cost inflation effect, to $\alpha_{5}$. If $\alpha_{4}, \alpha_{5}$ and $\alpha_{6}$ equal zero, retailing can be considered to be inflation-neutral: it does not create inflation itself, but it also does not form a buffer against it. Next to these research questions we aim at obtaining some results on the determinants of growth or decline in the number of retail stores in shoptypes.

\section{Data}

We use a data set of 36 Dutch shoptypes for the period 1977 through 1988 . The source of the data is an ongoing panel of independent, mainly small Dutch retailers called 'Bedrijfssignaleringssyteem' (interfirm comparison system) which is operated by the Research Institute for Small and MediumSized Business (EIM) in Zoetermeer. The shoptypes and the observation periods are given in Table I. It is important to recognize that the observation periods are not equal for each shoptype. We have a total of 341 data points while on average a data point is computed using observations from about seventy individual retail stores. Data concerning consumer spendings and modal 
TABLE I

Shoptypes, sample period and some averaged shoptype data

\begin{tabular}{|c|c|c|c|c|c|}
\hline Shoptype & Period & $P R O$ & $C A P$ & $\Delta \pi-\Delta Q$ & $\triangle N O F$ \\
\hline Supermarket with butcher's shop & $1977-88$ & 61.6 & 527.6 & 0.048 & -0.023 \\
\hline Self-service grocers & $1977-88$ & 26.4 & 204.3 & 0.089 & -0.023 \\
\hline Butchers & $1981-88$ & 40.2 & 183.3 & -0.018 & -0.008 \\
\hline Greengrocers & $1977-88$ & 32.5 & 127.6 & 0.071 & -0.016 \\
\hline Dairy shops & $1981-88$ & 29.9 & 121.4 & 0.041 & -0.030 \\
\hline Fish shops & $1981-88$ & 31.2 & 152.4 & -0.051 & 0.006 \\
\hline Bakers & $1981-88$ & 61.5 & 370.1 & -0.001 & -0.002 \\
\hline Supermarkets without butcher's shop & $1977-83$ & 61.0 & 357.0 & 0.064 & -0.030 \\
\hline Confectioners & $1981-88$ & 50.3 & 280.2 & 0.021 & -0.016 \\
\hline Tobacco shops & $1981-88$ & 31.5 & 132.7 & -0.025 & -0.036 \\
\hline Textiles mens wear & $1977-88$ & 68.9 & 388.2 & 0.048 & 0.015 \\
\hline Textiles ladies wear & $1977-88$ & 56.1 & 394.1 & 0.028 & 0.015 \\
\hline Textiles ladies and mens wear & $1977-88$ & 64.3 & 498,6 & 0.010 & 0.015 \\
\hline Textiles leisure wear & $1981-88$ & 56.5 & 359.5 & 0.059 & 0.014 \\
\hline Textiles underwear & $1981-88$ & 44.0 & 298.4 & 0.066 & 0.014 \\
\hline Non-specialized textiles & $1981-88$ & 33.4 & 333.8 & 0.002 & 0.014 \\
\hline Shoes & $1977-88$ & 51.9 & 342.6 & -0.003 & -0.006 \\
\hline Sporting goods & $1981-88$ & 45.4 & 448,6 & -0.108 & 0.021 \\
\hline Household goods & $1981-88$ & 32.2 & 324.4 & -0.014 & -0.002 \\
\hline Toys & $1981-88$ & 32.6 & 354.7 & -0.018 & 0.021 \\
\hline Electrical appliances, more than $25 \%$ repairs & $1981-87$ & 55.9 & 466.7 & 0.022 & -0.015 \\
\hline Electrical appliances, mixed assortment & $1981-87$ & 45.8 & 361.3 & 0.034 & -0.002 \\
\hline Furnishing stores, mainly fumiture & $1977-88$ & 82.9 & 643.4 & 0.025 & -0.005 \\
\hline Furnishing stores, mainly clothing material & $1977-88$ & 58.0 & 334.5 & 0.055 & 0.015 \\
\hline Furnishing stores, mixed assortment & $1977-88$ & 77.1 & 686.7 & 0.008 & -0.002 \\
\hline Paint, glass, wall-paper & $1981-88$ & 43.3 & 188.0 & 0.034 & -0.033 \\
\hline Ironmongers/do-it-yourself shops & $1981-88$ & 43.3 & 313.6 & 0.130 & -0.014 \\
\hline Bicycles & $1977-88$ & 31.6 & 248.2 & 0.003 & -0.016 \\
\hline Photographer's shops & $1981-88$ & 50.0 & 304.3 & 0.030 & 0.002 \\
\hline Watches, gold, silver & $1977-88$ & 56.4 & 447.1 & -0.000 & 0.003 \\
\hline Sewing-machines & $1981-88$ & 32.8 & 225.6 & 0.124 & 0.009 \\
\hline Stationer's stores & $1981-88$ & 57.1 & 453.0 & 0.036 & 0.010 \\
\hline Druggists & $1977-88$ & 43.2 & 284.1 & 0.008 & -0.014 \\
\hline Florists & $1977-88$ & 24.5 & 136.5 & -0.026 & 0.028 \\
\hline Gardening centres & $1981-88$ & 39.1 & 393.6 & 0.140 & 0.022 \\
\hline Pet shops & $1981-88$ & 23.9 & 161.9 & 0.040 & 0,003 \\
\hline
\end{tabular}

Note: The variables $P R O$ and $C A P$ stand for the average level of profit and total capital in thousand Dutch guilders in 1980 prices. The variables $\triangle \pi-\triangle Q$ and $\triangle N O F$ stand for the average value of the change in the logarithm of profit divided by sales and the change in the logarithm of number of firms, respectively,

Source: Central Registration Office and Research Institute for Small and Medium-Sized Business.

income were gathered by the Central Bureau of Statistics (CBS) in Voorburg, unemployment data were retrieved from the United Nations Monthly Bulletin of Statistics and data concerning entry and exit were gathered by the Central Registration Office (CRK) in The Hague.

Table I shows that average profit (in 1980 prices) ranges from 23,900 guilders for pet shops to 82,900 guilders for furnishing stores with mainly furniture. ${ }^{14}$ The average amount of capital (in 1980 prices), defined as the value of total assets as it occurs on the balance sheet, ranges from 121,400 guilders for dairy shops to 686,700 guilders for furnishing stores with mixed assortment. The extremes for the change in profitability are -0.108 for sporting goods stores and 0.140 
for gardening centres. For net entry these figures are -0.036 for tobacco shops and 0.028 for florists. ${ }^{15}$ Summary statistics for the variables in equations (1) and (2) can be found in Table II.

TABLE II

Summary statistics of the variable used

\begin{tabular}{lrrrr}
\hline Variable & MIN & MAX & MEAN & STD \\
\hline$\Delta \pi_{i t}-\Delta Q_{i t}$ & -1.14 & 0.94 & 0.027 & 0.241 \\
$\pi_{i, t-1}-M I_{t-1}$ & -1.32 & 1.09 & 0.100 & 0.431 \\
$\Delta N O F_{i t}$ & -0.11 & 0.10 & -0.002 & 0.026 \\
$\Delta T U R_{i t}$ & -1.72 & 1.63 & 0.018 & 0.219 \\
$\Delta M I_{t}$ & -0.03 & 0.02 & -0.001 & 0.016 \\
$\Delta K_{i t}-\Delta Q_{i t}$ & -0.19 & 0.56 & 0.000 & 0.065 \\
$\Delta \Delta C S_{i t}$ & -0.29 & 0.19 & 0.000 & 0.066 \\
$\Delta C S_{i, t-1}$ & -0.22 & 0.24 & -0.001 & 0.062 \\
$U N_{t-1}$ & 5.32 & 6.71 & 6.176 & 0.533 \\
$\Delta N O F_{i, t-1}$ & -0.11 & 0.11 & -0.003 & 0.026 \\
\hline
\end{tabular}

Note: MIN, MAX, MEAN and STD stand for the minimum, maximum, mean and standard deviation.

\section{Empirical results}

In this section we discuss the empirical results of the model estimated using the entire data set of 36 industries for the 12 year period 1977-1988, for the 6 year periods $1977-1982$ and 1983-1988 and two groups of 18 industries arranged according to average amount of capital in 1980 prices (see Table I). The use of subsets enables to check on time and cross-section stability of our model. The estimation results for equations (1) and (2), using Three Stages Least Squares from the SASmodule SYSNLIN, can be found in Table III. The long-term relationship follows as:

$$
\pi_{i t}=M I_{t}+0.533-0.039 U N_{t}
$$

In case of an unemployment of 500,000 people (about $8 \%$ of the Dutch labour force; unemployment ranges between 150,000 and 850,000 people in the period 1977-1988) the long-term profit is equal to about 1.34 times modal income. This coefficient just above one is not unreasonable as starting and running a store is a comparatively simple entrepreneurial activity when compared to starting a firm in most other sectors of the economy,
What answers can we give to the first two research questions brought forward in Section 2 ?

(1) With regard to the decomposition of sources of competition, we find $\hat{\alpha}_{1}, \hat{\alpha}_{2}$ and $\hat{\alpha}_{3}$ to be negative as expected, but only $\hat{\alpha}_{1}$ differs significantly from zero. The competition from incumbants seems therefore to outweigh competition from new firms and potential entrants. The process of dynamic competition indeed seems to erode excess profits over time.

(2) With regard to the decomposition of sources of inflation, we find $\hat{\alpha}_{6}$ to be insignificant. This would point at the absence of demand inflation. ${ }^{16}$ The parameter estimate $\hat{\alpha}_{4}$ is positive but not significant. This indicates that there is also no wage inflation: developments in general income level appear not to change profitability in the retail trade. A most interesting result is the significant negative effect of short-run cost changes on the development of profitability. We may consider retailing to be a subduing factor in the cost inflation process because cost rises are not immediately passed entirely on to customers.

Profitability, demand growth and unemployment all seem to have a positive effect on net entry. Like Acs and Audretsch (1989) we find demand growth to have a far stronger effect on net entry than profitability. Growing consumer spending may cause viable sub-market niches to emerge. These are especially attractive for small independents to enter. Unemployment has a significant upward effect on the number of firms. We must however be careful when making inferences on the parameter estimate $\hat{\beta}_{3}$. Unemployment measures are unreliable measures of the tension on the labour market, because of the sustained high unemployment level in the Netherlands. ${ }^{17}$ Net entry influences next period net entry strongly. In case this is mainly caused by following "success stories", it may point at a lack of rationality on the part of some individuals starting a retail store. The life cycle indicator, $\triangle T U R_{i t}$, influences net entry positively, as expected.

In Table III the results are presented for equations (1) and (2) for the periods 1977-1982 and 1983-1988, separately. This allows investigation of whether parameters differ between a 
TABLE III

Estimation results of the profitability and net entry equations

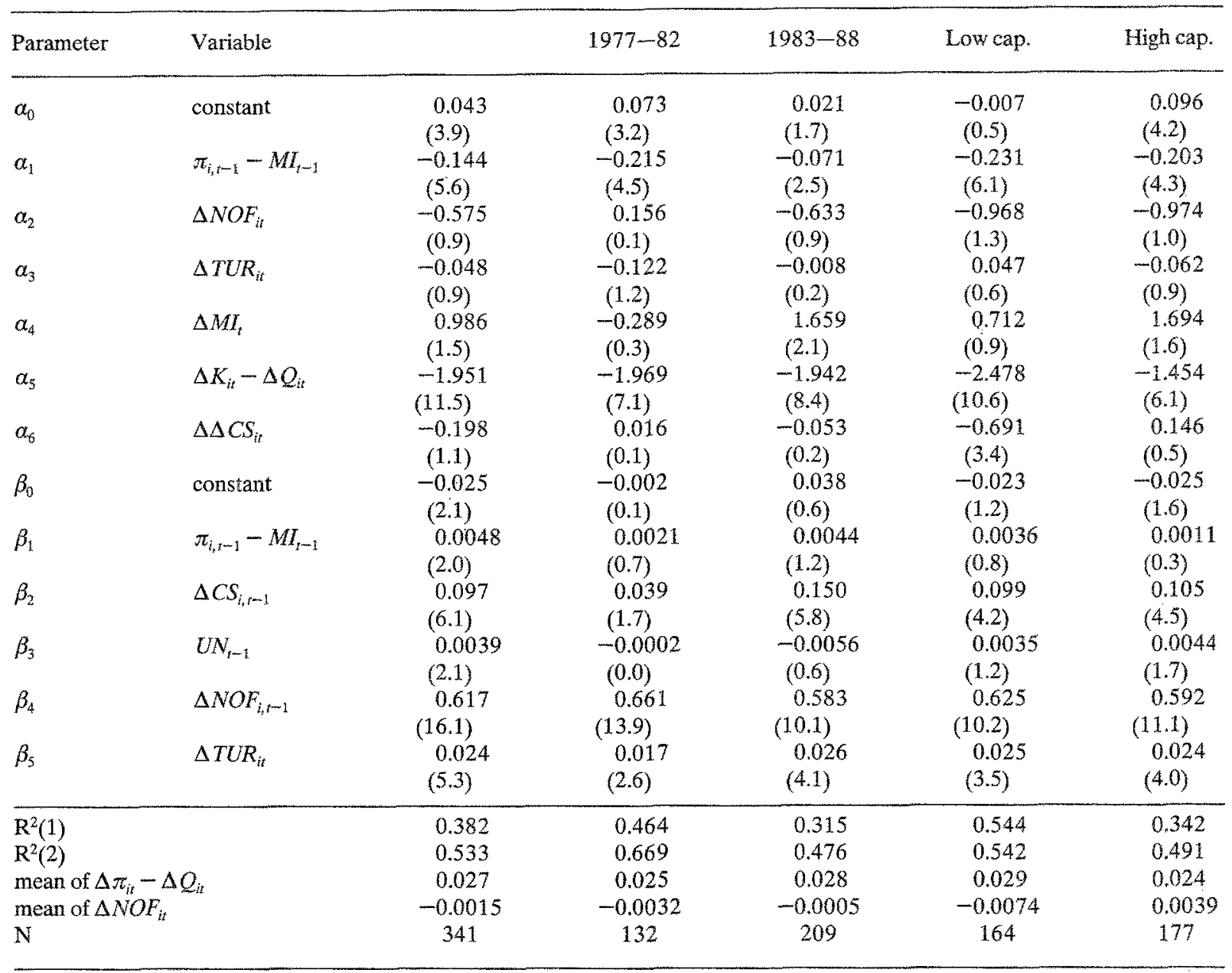

Note: The estimation results are for the total data set, the periods 1977-1982 and 1983-1988, the eighteen shoptypes with lowest and highest average capital, respectively. $R^{2}(1)$ and $R^{2}(2)$ stand for the $R$-squared of equations (1) and (2). Numbers in parentheses are t-statistics.

period of decline and growth, because the period 1977-1982 can be considered to be a period of constant economic decline and the period 19831988 of constant economic growth. The estimation of the model on distinct periods provides valuable information with regard to the third research question raised in Section 2:

(3) Actual competition from incumbants is more intense in the period of contraction 19771982 than in the recovery period 19831988. For actual competition from new firms we find the opposite: $\hat{a}_{2}$ declines from 0.156 to $-0.633 .{ }^{18}$ This finding can be explained as follows: In the period until 1982 firms generally employed strategies to protect marketshares in order to survive. This led to increased market competition. ${ }^{19}$ An important development in retailing in the period after 1982 has been the introduction of new shop formulas, generating a kind of creative destruction in the retail trade. Entering firms employing a new shop formula presumably have a competitive advantage over "traditional" stores. 
In Table III we also present the results for equation (1) and (2) estimated for the 18 shoptypes with the lowest average capital and for the 18 shoptypes with the highest average capital. The most important findings are as follows:

(4) The degree to which cost changes are passed on to customers is generally higher for larger firms (measured in amount of capital). This might be a consequence of larger firms usually having a better monitoring system, making a shorter reaction time on cost change possible. Larger firms generally have higher long-term profits. This is directly visible by considering the difference in $\hat{\alpha}_{0}$ across the two shoptype categories. These differences can be connected to the compensation for higher capital requirements, higher risk and higher responsibility for shopkeepers in larger stores. There is no indication of incentives for small store entry and large store entry to be different.

\section{Summary and discussion}

In this paper we empirically examine the importance of different sources of competition in retailing and the role of retailing in the inflationary process. We find potential competition to have no significant influence on changes in profitability. The results also indicate a shift from the effect of competition of existing to new firms around 1982. Retailing seems to be a subduing factor in the cost inflationary process. Cost inflation is suppressed especially in shoptypes dominated by firms with low average size. Net entry is strongly influenced by lagged demand growth and moderately influenced by lagged profitability and unemployment. We find the net entry process to be highly autocorrelated and to depend on the shoptype life cycle as measured by market turbulence.

Future research should be concerned with the implementation of the model on retail data of different countries (replication) and on data of manufacturing industries or other service industries (generalization). More sophisticated panel data techniques should be pursued. An important issue when applying the model is the long-term relationship of profits to some benchmark. In this paper we used modal income as benchmark because small independents were the subject of research. For large enterprise one may think of some function of the ratio of return on investment to the interest rate.

\section{Acknowledgements}

The authors wish to thank Kees Bakker and Herman van Schaik of the Research Institute for Small and Medium-Sized Business (EIM) for providing and elaborating the data. The authors are also grateful to Johan Koerts for helpful comments.

\section{Notes}

1 The percentage employment shares (in 1986) of retailing in the total labour force (non-private sector included) are 7.8 for the Netherlands, 8.3 for Germany, 8.5 for the United Kingdom, 6.7 for France, 9.6 for Italy, 16.7 for Spain and 9.2 for the United States (source: Ravesloot and Vogelesang (1989)).

2 Schultz and Kirzner clearly depart from the Schumpeterian notion of entrepreneurship. Schumpeter focused on the innovative aspects of entrepreneurship and regards the entrepreneur rather as creator of disequilibria than of equilibria. See Hébert and Link (1989) for a discussion of these different opinions on the nature and role of the entrepreneur.

${ }_{3}$ Variables which might play a role in establishing a longterm benchmark for the number of firms are for example mobility, urbanization, consumer preferences and scale economies. See Flath (1990) for a recent investigation of the determinants of the number of small retail firms for Japan.

4 The speed of profit adjustment to its long run equilibrium value is subject of research in the persistence of profits literature. Mueller (1990) regards this speed of convergence as central to the discussion of economic competition, because "if convergence is quick and complete, then competition among existing firms within an industry, the entry and exit of firms, and the threatened entry of firms must be presumed to be sufficiently swift and strong to bring firm and industry profit rates quickly back to their long run competitive equilibrium levels" (p. 6). With the inclusion of net entry $(\triangle N O F)$ and ease of entry and exit ( $\triangle T U R)$ we distinguish between the effects of these three possible sources of competition.

5 Beesley and Hamilton (1984) describe however the important role of this competitive fringe as seedbed of the new initiatives from which will emerge the successful firms of the future.

6 Highly turbulent industries are often characterized by low survival rates, indicating that high accessibility also implies large competitive pressure on many small new firms. For U.S. manufacturing industries, Dunne, Roberts and Samuelson (1988) find that "industries with higher than average entry rates also tend to have higher than average exit rates" (p. 508) indicating that entry induces exit through displacement (Flynn 
(1991), Shapiro and Khemani (1987)). Variables of turbulence are also used in Audretsch (1991), Audretsch and Acs (1990), Beesley and Hamilton (1984) and Johnson (1989).

7 Nooteboom, Kleijweg and Thurik (1988), using 16 Dutch shoptypes for the period 1976-1983, find that deviations from "normal costs" are passed on to customers for only about fifty percent.

8 De Wit and Van der Winden (1990) use the difference between logarithms of profit in case of self-employment and wage in case of wage-employment to determine whether an individual chooses to become self-employed. They find a greater probability of becoming self-employed when this difference grows. The effect of excess profit on net entry at shop type level can be seen as aggregation of individuals making decisions on entry and exit on the basis of their perceived discrepancies between attainable profit as shopkeeper and wage as employee.

9 See Schmalensee $(1989$, p. 997$)$ for studies relating entry to profitability. The expected positive influence of profitability on net entry is found just as often as no influence. Acs and Audretsch (1989) report however that the positive influence is usually found in the empirical literature.

10 See Schmalensee $(1989$, p. 997) for studies relating entry to growth. Some studies find a positive influence of growth on entry, others find no relation. Acs and Audretsch (1989) summarize however that the industrial rate of growth is found to positively infuence entry in most studies. Their own empirical results show that the entry-inducing effect for small manufacturing firms from growth is much stronger than that from lagged profitability. This may indicate that small firms are attracted by sub-market niches rather than by average profitability (see also Bradburd and Ross (1989)). Evans and Leighton (1989b) find that the share of self-employment in total employment rises in an expanding economy.

11 See Storey (1991) for a recent survey of studies of the effect of unemployment on new-firm births. He finds timeseries analyses to point to unemployment being positively associated with indices of new-firm formation, whereas cross sectional studies generally indicate the reverse. Highfield and Smiley (1987) present a more comprehensive study of the influence of microeconomic and macroeconomic factors on the entry process. We expect that the effect of unemployment on the number of firms will be higher in the United States than in the Netherlands because of the well-developed Dutch social security system. There is probably a lower pressure on Dutch unemployed workers to become self-employed.

12 This is related to the demonstration effect of Gort and Konakayama (1982): Perceptions of profit opportunities are positively related to the successful experience of others in the market.

13 This pattern was also encountered for the number of firms selling recently developed products (Klepper and Graddy (1990)).

14 In the period 1977 through 1988 the Dutch guilder ranged between $\$ 0.30$ and $\$ 0.50$.

15 Data on entry and exit were not always available for each shoptype separately. In these cases we used aggregated data instead. This implies that $\triangle N O F$ and $\triangle T U R$ can be identical for similar shoptypes.
16 In earlier studies, like Nooteboom (1985) and Nooteboom, Kleijweg and Thurik (1988), empirical evidence, however, is found for a positive effect for growing demand on retail price setting.

17 Another problem is the low variability of $U N_{f}$. The estimated correlation between $\hat{\beta}_{0}$ and $\hat{\beta}_{3}$ is -0.996 , making inference about the effect of the height of unemployment on the increase of the number of firms difficult.

18 The decline of $\hat{\alpha}_{2}$ is not significant. We must however also take into account that the correlation of the residuals of equations (1) and (2) declines from 0.078 to -0.047 (for the 1977-1988 period it equals 0.033 ). The OLS-estimates for $\alpha_{2}$ are 0.596 (t-value is 0.7 ) for the $1977-1982$ period and -0.775 (t-value is 1.8) for the 1983-1988 period.

19 Kessides (1990) finds the speed of adjustment of profits to their long-run equilibrium to the negatively related to growth of demand in an industry. He ascribes this result to greater volatility of internal market share competition and destabilizing effects of entry in slow growth industries.

\section{References}

Acs, Z.J. and D. B. Audretsch, 1989, "Small-firm Entry in US Manufacturing', Economica 56, 255-265.

Audretsch, D. B., 1991, 'The Technological Regime and Small-Fim Turbulence, International Small Business Joumal 9, 80-97.

Audretsch, D. B. and Z. J. Acs, 1990, "The Entrepreneurial Regimes, Learning, and Industry Turbulence', Small Business Economics 2, 119-128.

Beesley, M. E. and R. T. Hamilton, 1984, 'Small Firms' Seedbed Role and the Concept of Turbulence', Journal of Industrial Economics 33, 217-231.

Bode, B., 1990, Studies in Retail Pricing, Ph.D.-thesis, Erasmus University Rotterdam.

Bradburd, R. M. and D. R. Ross, 1989, 'Can Small Firms Find and Defend Strategic Niches? A Test of the Porter Hypothesis;, Review of Econonics and Statistics 71, $258-262$.

Dunne, T., M. J. Roberts and L. Samuelson, 1988, 'Parterns of Firm Entry and Exit in U.S. Manufacturing Industries', RAND Joumal of Economics 19, 495-515.

Evans, D. S. and L. S. Leighton, 1989a, 'Some Empirical Aspects of Entrepreneurship', American Economic Review 79, 519-535.

Evans, D. S. and L. S. Leighton, $1989 \mathrm{~b}$, The Determinants of Changes in U.S. Self-employment, 1968-1987', Small Business Economics 1, 111-119.

Flath, D., 1990, 'Why Are There So Many Retail Stores in Japan?', Japan and the World Economy 2, 365-386.

Flynn, J. E., 1991, 'The Determinants of Exit in an Open Economy', Small Business Economics 3, 225-232.

Gilbert, C. L, 1986, 'Professor Hendry's Econometric Methodology, Oxford Bulletin of Economics and Statistics 48, 283-307.

Gilbert, R. J., 1989, "The Role of Potential Competition in Industrial Organization', Journal of Economic Perspectives 3, 107-127. 
Gort, M. and A. Konakayama, 1982, 'A Model of Diffusion in the Production of an Innovation', American Economic Review 72, 1111-1120.

Hébert, R. F. and A. N. Link, 1989, In Search of the Meaning of Entrepreneurship', Small Business Economics 1, 3949.

Herck, G. van, 1984, 'Entry, Exit and Profitability', Managerial and Decision Economics 5, 25-31.

Highfield, R. and R. Smiley, 1987, 'New Business Starts and Economic Activity: An Empirical Investigation', International Journal of Industrial Organization 5, 51-66.

Ikeda, S., 1990, "Market-process Theory and "Dynamic" Theories of the Market", Southern Economic Journal 57 , $75-92$.

Johnson, P., 1989, 'Employment Change in the Small Business Sector: Evidence from Five Manufacturing Industries', Small Business Economics 1, 315-323.

Kessides, I. N., 1990, 'The Persistence of Profits in U.S. Manufacturing Industries', in $\mathrm{D}$. C. Mueller (ed.), The Dynamics of Company Profits: An International Comparison, Cambridge: Cambridge University Press.

Kirzner, I. M., 1973, Competition \& Entrepreneurship, Chicago: University of Chicago Press.

Kirzner, I. M., 1979, Perception, Opportunity and Profit: Studies in the Theory of Entrepreneurship, Chicago: University of Chicago Press.

Klepper, S. and E. Graddy, 1990, 'The Evolution of New Industries and the Determinants of Market Structure', RAND Journal of Economics 21, 27-44.

Liebowitz, S. J. 1982, 'Measuring Industrial Disequilibria', Southern Economic Joumal 48, 119-136.

MacDonald, J. M., 1986, 'Entry and Exit on the Competitive Fringe', Southern Economic Journal 52, 640-652.

Mueller, D. C., 1977, "The Persistence of Profits Above the Norm', Economica 43, 369-380.

Mueller, D. C., 1990, 'Profits and the Process of Competi- tion', in D. C. Mueller (ed.), The Dynamics of Company Profits: An International Comparison, Cambridge: Cambridge University Press.

Nooteboom, B., 1985, 'A Mark-up Model of Retail Margins', Applied Economics 17,647-667.

Nooteboom, B., A. J. M. Kleijweg and A. R. Thurik, 1988, Normal Costs and Demand Effects in Price Setting: A Study of Retailing', European Economic Review 32, 999-1011.

Porter, M. E., 1976, Interbrand Choice, Strategy and Bilateral Market Power, Cambridge: Harvard University Press.

Ravesloot, T. K. and W. J. P. Vogelesang, 1989, Facts and Figures on Retailing in the Netherlands, Europe and the US, Zoetermeer: Research Institute for Small and MediumSized Business.

Salmon, M., 1982, 'Error Correction Mechanisms', Economic Journal 92, 615-629.

Schmalensee, R., 1989, 'Inter-industry Studies of Structure and Performance', in R. Schmalensee and R. D. Willig (eds.), Handbook of Industrial Organization, Vol. II, Amsterdam: Elsevier Science Publishers.

Schultz, T. W., 1975, 'The Value of the Ability to Deal with Disequilibria', Journal of Economic Literature 13, 827846.

Shapiro, D. and R. S. Khemani, 1987, "The Determinants of Entry and Exit Reconsidered', International Journal of Industrial Organization 5, 15-26.

Storey, D. J., 1991, 'The Birth of New Firms - Does Unemployment Matter? A Review of the Evidence', Small Business Economics 3, 167-178.

Storey, D. J. and A. M. Jones, 1987, 'New Firm Formation A Labour Market Approach to Industrial Entry', Scottish Journal of Political Economy 34, 37-51.

Wit, G. de, and F. Van der Winden, 1990, 'An Empirical Analysis of Self-employment in the Netherlands', Economics Letters 32, 97-100. 